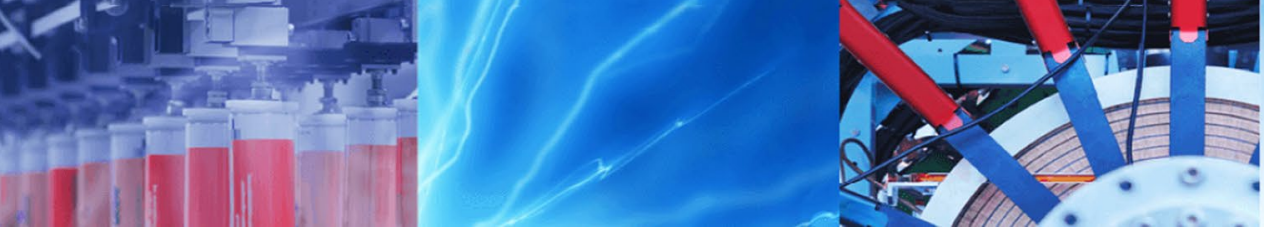

Research Article

\title{
Characterization and efficient dye discoloration of Algerian diatomite from Ouled Djilali-Mostaganem
}

\author{
Amal Touina ${ }^{1,2} \mathbb{D} \cdot$ Safia Chernai ${ }^{1,2} \cdot$ Bouhameur Mansour $^{3} \cdot$ Hafida Hadjar $^{4} \cdot$ Abdelkader Ouakouak $^{5} \cdot$ \\ Boualem Hamdi ${ }^{1,2}$
}

Received: 16 November 2020 / Accepted: 3 February 2021 / Published online: 20 March 2021

(c) The Author(s) $2021 \quad$ OPEN

\begin{abstract}
A series of naturally occurring diatomaceous earth samples from Ouled Djilali, Mostaganem (Lower Chelif basin, Algeria northwestern), were investigated, which are characterized by the expansion and evolution during the Messinian age. Four varieties of diatomite were distinguished, characterized, and successfully used to adsorb methylene blue dye in aqueous medium. Several properties and characteristics of diatomite have been outlined using analytical methods such as X-ray fluorescence spectrometry, X-ray diffraction (XRD), Fourier transform infrared spectroscopy (FTIR), $\mathrm{N}_{2}$ adsorption-desorption (BET), and scanning electron microscopy (SEM), as well as other complementary analysis tests. Results showed that silica and calcium carbonates were the main constituents of the diatomite samples (ranging between 32.8 and $61.5 \%$ for $\mathrm{SiO}_{2}$; and 13.8-25.9\% for $\mathrm{CaO}$ ), with a slight difference in chemical composition between selected samples. Typical for all diatomite samples, the XRD analysis suggests a high mass quantity of amorphous phase (Opal); high content of crystal phase was also registered. FTIR allowed determining the basic characteristic silica bands regarding diatomite samples. While the BET and SEM investigations revealed that the studied diatomite material has a highly porous structure and was very rich in diatoms. The maximum adsorption capacity of methylene blue that was calculated from the Langmuir isotherm model was $116.59 \mathrm{mg} / \mathrm{g}$ (for Ouled Djilali: OD05 sample) at $25^{\circ} \mathrm{C}$ and pH 7.0. The diatomite from Mostaganemian (Ouled Djilali) deposit may find promising applications as low-cost adsorbent for dyes removal from water.
\end{abstract}

Keywords Diatomite $\cdot$ Characterization $\cdot$ Adsorption $\cdot$ Methylene blue $\cdot$ Isotherm model

\section{Introduction}

Nowadays, water pollution has given rise to serious environmental problems [1]. Among the different contaminants affecting the aquatic ecosystems, dyes belong to one of the larger and most important groups generally discharged in wastewaters from industrial and agricultural sectors, which present considerable toxicity to human beings and living organisms [2]. Hence, the depollution of water from dyes has become of high priority concern. In response, several methods have been studied to assess their applicability and removal efficiency. Among these methods, adsorption especially onto activated carbon has been considered as the most effective and widely used one [3-7]. Nevertheless, due to the expensive price and difficult regeneration process of activated carbons, worldwide attention has been focused on finding out alternative adsorbents such as bentonite [8], waste sludge [9], maine

$\triangle$ Amal Touina, amaltouina@yahoo.com | 1 Laboratoire de Conservation et de Valorisation des Ressources Marines (LCVRM), Algiers, Algeria. ${ }^{2}$ Ecole Nationale Superieure des Sciences de la Mer et de l'Amenagement du Littoral (ENSSMAL), Campus Universitaire, Bois des Cars, Dely Ibrahim, BP 19, Algiers, Algeria. ${ }^{3}$ Laboratoire de Paléontologie Stratigraphique et Paléoenvironnements (LPSP), Université D'Oran 2 Ahmed Ben Ahmed, Oran, Algeria. ${ }^{4}$ CRAPC, Centre de Recherche Scientifique et Technique en Analyses Physico-Chimiques, Zone Industrielle, RP, BP 384, 42004 Bou-Ismaïl, Tipaza, Algeria. ${ }^{5} \mathrm{Hydraulic}$ and Civil Engineering Department, University of El Oued, El Oued, Algeria. 
algae (Ulva lactuca and Sargassum) [10], bagasse fly ash [11], and almond peel [12].

Diatomite, otherwise known as kieselguhr, diatomaceous earth (DE), or "Tripoli" of Sicily, is provided from the Messinian diatomitic formation [13]. It represents one of the most significant sedimentary events of the Neogene in the Mediterranean [14]. Diatomite is a silica rock consisting essentially of fossilized skeletal remains of single-celled aquatic algae called diatoms. It is characterized by the presence of a rigid skeleton made of hydrated silica (opal), called frustule [15], with a number of impurities such as inorganic and organic matters, and even clay minerals [16]. There are nearly 10,000 species of diatoms forming vast deposits of sedimentation in various parts of the earth. Due to its unique advantages and desirable properties, high porosity and small particle size, that give to the diatomite low density, high permeability, high adsorption capacity and specific surface area, and low thermal conductivity [17], the diatomite provides a wide variety of uses in sustainable development and environment such as purification of drinking water, filtration, insulation, adsorption, manufacture of antibiotics, catalysis, and as an additive in cement [18-20].

Algeria is considered to have rich area of natural DE deposits situated in a wide basin called Lower Chelif Basin. These deposits are still little exploited, since the most important exploitation is mainly concentrated on the site of Sig in western Algeria. The present contribution aims to first highlight the physicochemical, mineralogical and textural properties of a natural diatomite from the Mostaganemian deposit (Ouled Djilali) using various methods: $\mathrm{X}$-ray fluorescence spectrometry (XRF), X-ray diffraction (XRD), scanning electron microscopy (SEM), Fourier transform infrared spectroscopy (FTIR), and $\mathrm{N}_{2}$-BET (Brunauer, Emmett, and Teller) adsorption-desorption technique. Adsorption tests were thereafter conducted on the asstudied material to explore on the removal process efficiency of a cationic dye (methylene blue) from aqueous media. Different isotherm models were examined for analyzing the equilibrium data and for a better understanding of the adsorption process.

\section{Location and reserves of Lower Chelif Basin diatomite deposits}

\subsection{Lower Chelif Basin}

The current area of interest occurs along the northeastern border of the Lower Chelif Basin; in the northwestern region of Algeria is part of the Lower Chelif Basin (Fig. 1). The basin is regarded as the largest intramountainous basin in the north of Algeria [21], in the same way as the large marginal Neogene basins of the Mediterranean [22].
Geomorphologically, it is a long depression (ENE/WSW direction) over about $350 \mathrm{~km}$ and $35 \mathrm{~km}$ wide. It is limited to the north by the Oranean coast (Djebel Murdjadjo, Arzew mountains) and Dahra mountains. Tessala, Beni Chougrane, Ouled Ali, and Ouarsenis Mounts represent its borders to the South.

\subsection{Ouled Djilali sampling area}

The selected diatomite sampling area is deposited in Ouled Djilali location southeastern part of Daira of Sidi Ali, throughout a distance of $11.92 \mathrm{~km}\left(\mathrm{~N}: 36^{\circ}, 02^{\prime}\right.$, and $36.2^{\prime \prime}$. E: $\left.000^{\circ}, 31^{\prime}, 44.4^{\prime \prime}\right)$. It is bounded on the north by Douar Gouassmia, Jebel Chaif Dahmane, and Douar El B'Hara, in the south by Douar Ouled Fellouh, and Douar Ouled Mokhtar, in the east by Douar Haddou, and in the west by Douar Soualmia and Douar Torche (Fig. 2).

\section{Materials and methods}

\subsection{Preparation of samples}

Four varieties of natural diatomite samples taken from each layer from the deposit of Ouled Djilali have been distinguished on the basis of the colors variability of the diatomite rocks, their structural and textural features, and their fracturing effects (Table 1; Fig. 3). The samples were denoted with the letters OD (according to the site name: Ouled Djilali), with additional numbers that correspond to the different layers.

The OD samples employed in this study were first dried at a temperature of $110^{\circ} \mathrm{C}$ overnight. After being crushed in HERZOG grinder in a tungsten bowl (3 min at $700 \mathrm{rpm}$ ), the samples were sieved to obtain a size fraction of $63 \mu \mathrm{m}$ (no refusal must remain) for characterization with X-ray diffraction and $X$-ray fluorescence methods, while a size fractions between 100 and $200 \mu \mathrm{m}$, served to allow easier analysis.

\subsection{Characterization}

The chemical compositions of the raw material were determined by X-ray fluorescence spectroscopy (XRF) (S8 TIGER de Bruker). X-ray powder diffraction data (XRD) were acquired with a BrukerD4 ENDEAVOR analyzer operating with a CuKa radiation source filtered with a graphic monochromator $\lambda=1.5406 \AA$. The surface morphology of the raw samples was illustrated by scanning electron microscopy (SEM), using « Philips XL 30 model ESEM-FEG» operating at $8 \mathrm{kV}$. The Fourier transform infrared (FTIR) spectra were obtained from a «Perkin Elmer» spectrometer 


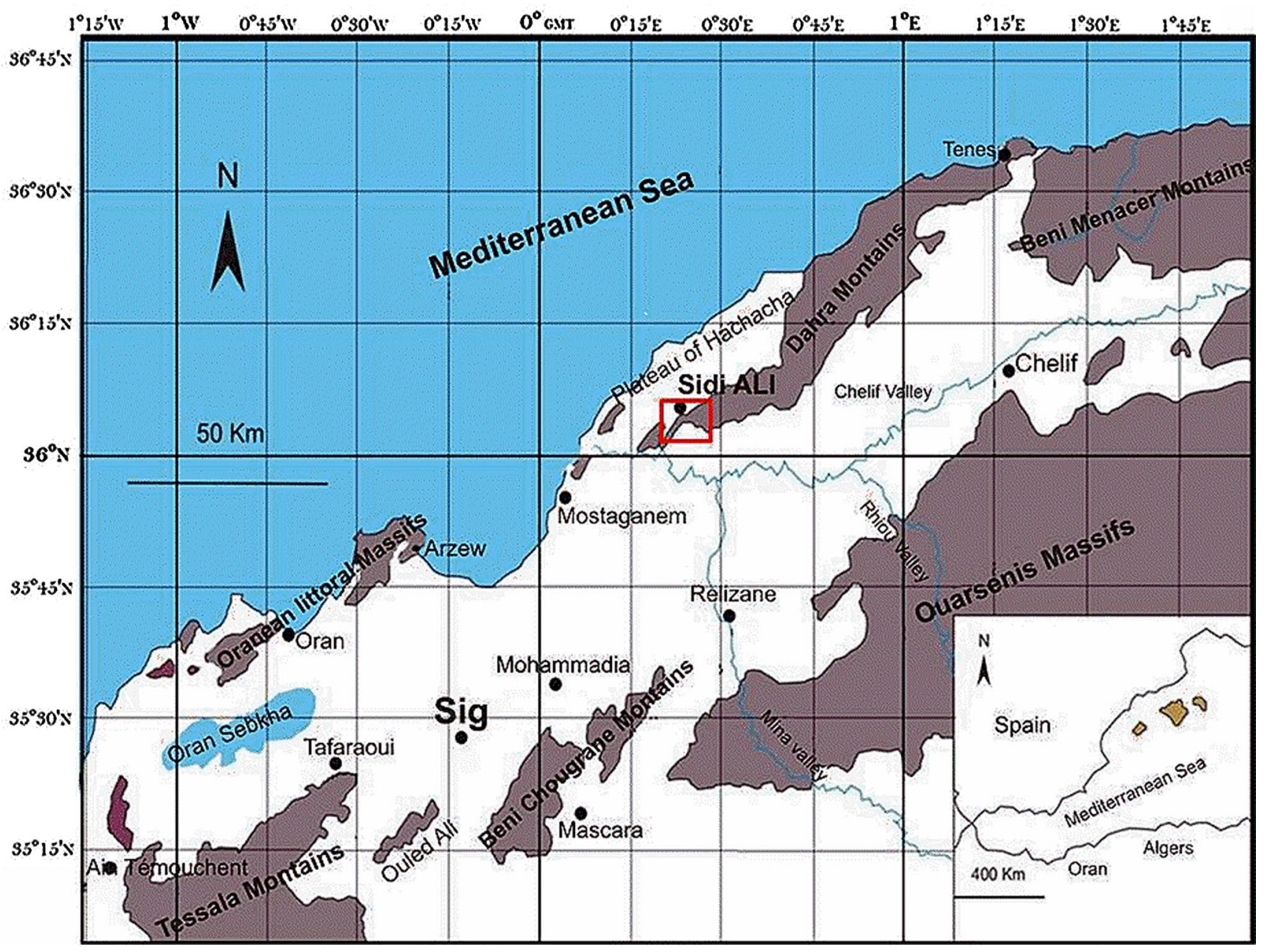

Fig. 1 Location of the studied site in the Lower Chelif Basin (Algeria) (CorelDRAW 12)

connected to a computer with the scanning range from 400 to $4000 \mathrm{~cm}^{-1}$.

The characterization of the specific surface area and Brunauer, Emmett and Teller (BET) texture parameters of Ouled Djilali diatomite was carried out by low-temperature adsorption of nitrogen (at $77.3 \mathrm{~K}$ ) using a Micromeritics ASAP-2420 surface area analyzer. The degassing of the diatomite samples was performed for $12 \mathrm{~h}$ at a heating temperature of $140^{\circ} \mathrm{C}$. The nitrogen adsorption-desorption isotherms were analyzed to evaluate the required parameters; the specific surface areas $\left(S_{B E T}\right)$ were determined on the basis of the BET equation. The total pore volume $\left(V_{t}\right)$ was estimated in accordance with the rule of Gurvich at a relative pressure of 0.977 . The volume of the mesopores $\left(V_{\text {mes }}\right)$ was evaluated from the difference between the total pore volume $\left(V_{t}\right)$ and that of the micropores $\left(V_{\text {mic }}\right)$.

\subsection{Physicochemical properties}

In this part, the diatomite samples were first crushed and sieved at $200 \mu \mathrm{m}$. Several physicochemical parameters were studied. For $\mathrm{pH}$ determination, diatomite suspensions ( $2 \mathrm{~g}$ of sample in $100 \mathrm{ml}$ of ultrapure water) were prepared in a beaker of $200 \mathrm{ml}$ volume. The mixtures were stirred for $6 \mathrm{~h}$, and the $\mathrm{pH}$ of the aqueous solutions was measured immediately on a $\mathrm{pH}$ meter model $\mathrm{Hi} 208$, Hanna instruments. For the chloride ion percentage, diatomite suspensions ( $1 \mathrm{~g}$ of diatomite in $75 \mathrm{ml}$ of ultrapure water) were boiled until a volume of $50 \mathrm{ml}$. After cooling, the content was filtered, and the chlorides percentage was estimated by MOHR's method (argentometric method) using silver nitrate as titrant and potassium chromate as indicator solution. The apparent density was expressed by means of the ratio between the mass of diatomite $(\mathrm{g})$ and 
the occupied volume $\left(\mathrm{cm}^{3}\right)$. The percentage of humidity was estimated by lyophilization process of the samples for $48 \mathrm{~h}$.

Regarding the water and oil adsorption rate, the determination of their values was obtained by calculation of the ratio between the maximum amount of oil (sunflower oil), or water adsorbed on the diatomite and its mass.

\subsection{Batch adsorption experiment}

The process of methylene blue (MB) dye removal was conducted under common batch adsorption experiments. Approximately, $0.1 \mathrm{~g}$ of the natural Ouled Djilali diatomite was put in contact with $50 \mathrm{~mL}$ of $\mathrm{MB}$ dye solution at different desired concentrations $(10,20,30,40,50$, $80,120,160$, and $200 \mathrm{mg} / \mathrm{L}$ ). Each adsorbent-adsorbate mixture was mechanically stirred at $125 \mathrm{rpm}$ at ambient temperature $\left(25^{\circ} \mathrm{C}\right)$ until it reached the adsorption equilibrium (according to preliminary results, the contact time was fixed to $60 \mathrm{~min}$ ). Following this, a $0.45 \mu \mathrm{m}$ membrane filter was used to separate each dye solution from the corresponding dye-diatomite interaction system. The residual concentration in the MB supernatant was analyzed using a UV-Vis spectrophotometer at the wavelength $\lambda_{\max }=665 \mathrm{~nm}$. All adsorption tests were performed at
$\mathrm{pH}=7.0$. The solutions involved were diluted to proper concentrations before making measurements. The quantity of adsorbed MB at equilibrium (qe, $\mathrm{mg} / \mathrm{g}$ ) was calculated as follows:

$q_{\mathrm{e}}=\left(C_{0}-C_{\mathrm{e}}\right) * V / m$

where $C_{0}$ and $C_{e}(\mathrm{mg} / \mathrm{L})$ are the concentration of $\mathrm{MB}$ ions at the beginning and the equilibrium concentration, respectively. $V(L)$ is the volume of $M B$ solution, whereas $m$ (g) represents the mass of diatomite adsorbent.

Regarding the modeling of the adsorption isotherm, Langmuir, Freundlich, Sips and Temkin isotherm models are well applied to describe the adsorption process. More detailed information and derivation of such models are summarized in Table 2.

\section{Results and discussion}

\subsection{Macroscopic properties}

The whitish raw OD diatomite material has a laminated structure with fine grains, releasing easily in hand. It can be scratched with no significant resistance. Whereas the

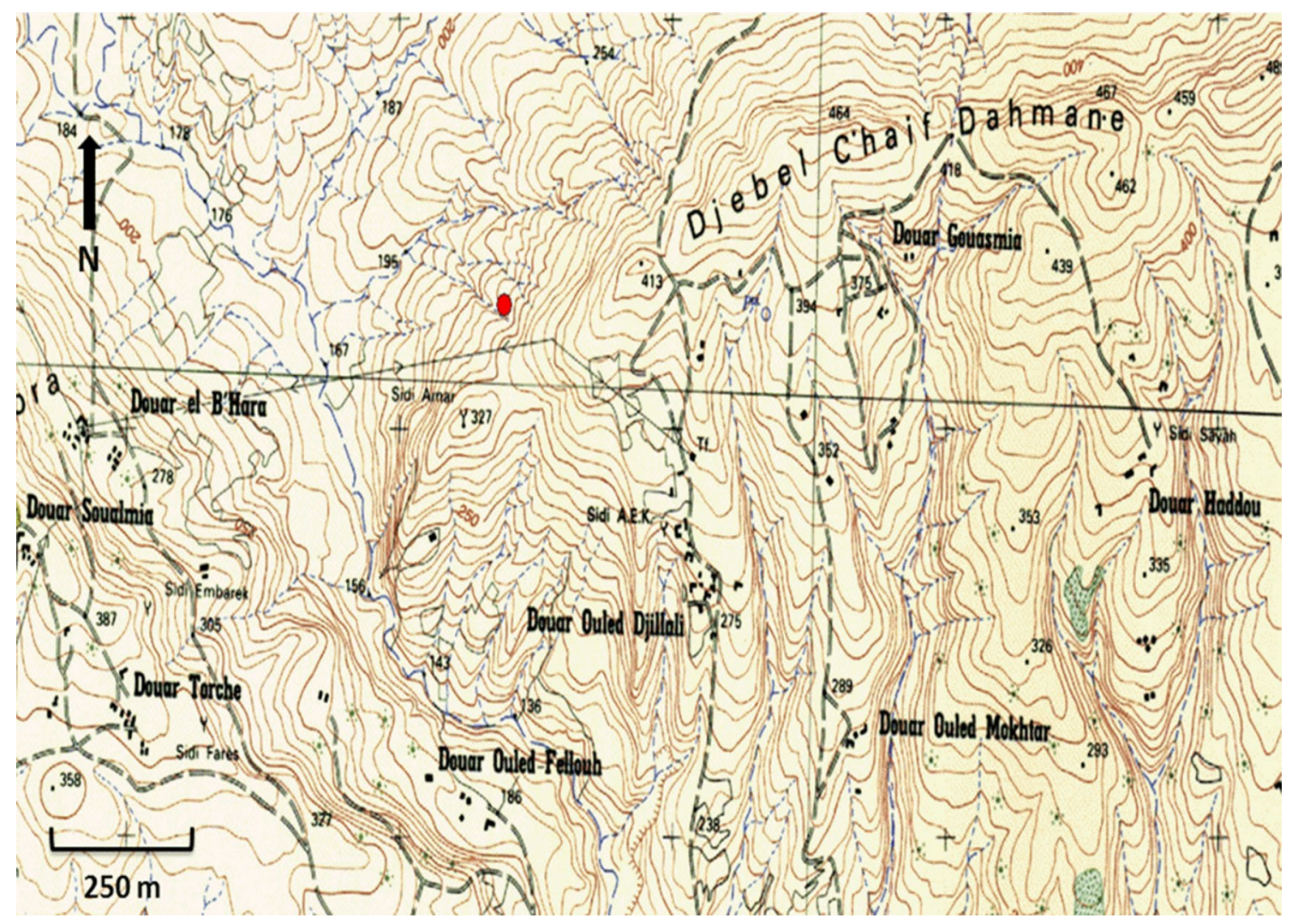

Fig. 2 Geographical location of the Ouled Djilali sampling area (N: $36^{\circ}, 02^{\prime}, 36.2^{\prime \prime}$. E: $\left.000^{\circ}, 31^{\prime}, 44.4^{\prime \prime}\right)$ (ARCGIS)

SN Applied Sciences

a SPRINGer Nature journal 
Table 1 Macroscopic description of natural diatomite samples from deposit of Ouled Djilali

\begin{tabular}{llll}
\hline Sample & Nature & Color & Features and fracturing effects \\
\hline OD03 & Diatomite & Whitish & Laminated, light, pulverous \\
OD04 & Diatomite & Whitish & ++ Laminated, light, pulverous \\
OD05 & Marly diatomite & Beige & Indurate, massive \\
OD08 & Marly diatomite & Beige & ++ Laminated, pulverous \\
\hline
\end{tabular}

+ More

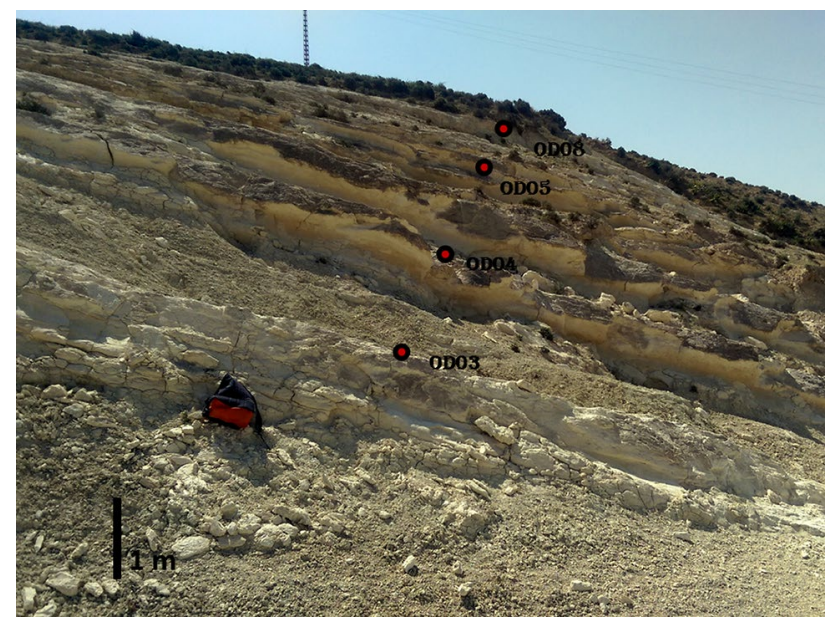

Fig. 3 Panoramic view of the studied site

darker samples are massive, indurate, and highly resistant, this required the use of a big grinding material (HERZOG grinder). They can be also laminated and easily crumbled in hand. The raw material is a lightweight sedimentary rock having strong water absorbability, which emphasizes a high porosity. Because the sampling was done during a rainfall period, the samples contained a large volume of water; significant time was thus required to release absorbed water from samples.

\subsection{Geochemical composition by XRF}

The geochemical composition of the natural OD diatomite samples was obtained by the X-ray fluorescence spectroscopy, expressed by means of weight percentages, as reported in Table 3. Loss-on-ignition represents the percentage of material removed during the air calcination of a sample at $950^{\circ} \mathrm{C}$. As can be seen, the XRF results depict that the main components of the raw OD diatomite consist of silica $\left(\mathrm{SiO}_{2}\right)$, with significant amounts of calcium (Ca) being mainly in the form of carbonate, whereas other mineral components, existing typically as impurities in minor amounts, contribute to the rest of the diatomite composition. Although the raw diatomite samples are located in the same deposit, the XRF results show significant differences in the $\mathrm{SiO}_{2}$ and $\mathrm{CaO}$ percentages between samples, in contrary of the other admixtures contents. The whitish raw materials are composed of $49.5-61.5 \% \mathrm{SiO}_{2}$, except for the indurate marl-diatomite (sample OD5) that contains only $32.8 \% \mathrm{SiO}_{2}$. The $\mathrm{CaO}$ content varies from 13.8 to $25.9 \%$ which generally does not depend on the diatomite variety distinguished on the base of the variability of rock colors, and textural features, as it is with the $\mathrm{SiO}_{2}$ content. The two OD04 and OD05 samples have the most elevated value of loss on ignition (LOI). They represent the darker colored diatomite varieties, and both their features (LOI and color) depend probably upon the presence of high amount of organic substances. Indeed, we notice in Table 3 that the rate in LOI is correlated with the rate in $\mathrm{CaO}$ (as aforementioned, $\mathrm{Ca}$ exists in the natural diatomaceous earth product as calcium carbonate $\left(\mathrm{CaCO}_{3}\right)$ which decomposes into $\mathrm{CaO}$ and $\mathrm{CO}_{2}$ above $800{ }^{\circ} \mathrm{C}$ ). The presence of high content of $\mathrm{SiO}_{2}$ in both $\mathrm{OD} 03$ and OD04 diatomite

Table 2 Equations and relevant parameters of the used isotherm models

\begin{tabular}{|c|c|c|c|}
\hline Isotherm models & Equation & Description parameters & References \\
\hline Langmuir & $q_{\mathrm{e}}=\frac{Q_{\max }^{0} K_{\mathrm{L}} C_{\mathrm{e}}}{1+K_{\mathrm{L}} C_{\mathrm{e}}}$ & $\begin{array}{l}C_{\mathrm{e}}: \text { concentration of } \mathrm{MB} \text { dye at equilibrium } \\
Q^{0}{ }_{\text {max }}(\mathrm{mg} / \mathrm{g}): \text { maximum monolayer adsorption capacity of Langmuir }\end{array}$ & [23] \\
\hline Freundlich & $q_{\mathrm{e}}=K_{\mathrm{F}} C_{\mathrm{e}}^{n}$ & $K_{\mathrm{L}}(\mathrm{L} / \mathrm{mg}):$ Langmuir constant & [24] \\
\hline Sips & $q_{\mathrm{e}}=\frac{Q_{\max }^{0} K_{\mathrm{s}} C_{\mathrm{e}}^{1 / n s}}{1+K_{\mathrm{s}} C_{\mathrm{e}}^{1 / n s}}$ & $\begin{array}{l}\left.\left.C_{\mathrm{F}}(\mathrm{mg} / \mathrm{L}) \text { : Inttial } / \mathrm{mg} / \mathrm{g}\right) /(\mathrm{mg} / \mathrm{L})^{n}\right]: \text { Freundlich constant } \\
n \text { : dimensionless Freundlich intensity parameter }\end{array}$ & [25] \\
\hline Temkin & $q_{\mathrm{e}}=\frac{R \cdot T}{\Delta Q} \cdot \ln \left(K \cdot C_{\mathrm{e}}\right)$ & $\begin{array}{l}Q^{0}{ }_{\max }(\mathrm{mg} / \mathrm{g}): \text { the Sips maximum adsorption capacity } \\
K_{\mathrm{S}}(\mathrm{mg} / \mathrm{L})^{-1 / n}: \text { the Sips equilibrium constant } \\
n: \text { the exponent of Sips where } 0<1 / \mathrm{ns} \leq 1 \\
\Delta \mathrm{Q}(\mathrm{J} / \mathrm{mol}): \text { the heat transfer } \\
R(R=8.314 \mathrm{~J} / \mathrm{mol} / \mathrm{K}) \text { : the universal gas constant } \\
T(\mathrm{~K}) \text { : the temperature }\end{array}$ & {$[26]$} \\
\hline
\end{tabular}


Table 3 Geochemical composition of the natural diatomite samples of Ouled Djilali section (in Weight (\%))

\begin{tabular}{lcccc}
\hline Samples & OD03 & OD04 & OD05 & OD08 \\
\hline $\mathrm{SiO}_{2}$ & 61.52 & 58.9 & 32.8 & 49.5 \\
$\mathrm{Al}_{2} \mathrm{O}_{3}$ & 3.88 & 3.55 & 5.7 & 3.44 \\
$\mathrm{Fe}_{2} \mathrm{O}_{3}$ & 1.66 & 1.5 & 2.26 & 1.53 \\
$\mathrm{CaO}$ & 13.8 & 15.2 & 25.9 & 21.7 \\
$\mathrm{MgO}$ & 1.53 & 1.42 & 3.14 & 0.4 \\
$\mathrm{SO}_{3}$ & 0.1 & 0.1 & 0.15 & 0.12 \\
$\mathrm{~K}_{2} \mathrm{O}$ & 0.84 & 0.79 & 0.49 & 0.7 \\
$\mathrm{NaO}_{2}$ & 0.21 & 0.22 & 1.26 & 0.32 \\
$\mathrm{P}_{2} \mathrm{O}_{5}$ & 0.05 & 0.06 & 0.07 & 0.07 \\
$\mathrm{TiO}_{2}$ & 0.19 & 0.18 & 0.29 & 0.17 \\
$\mathrm{Cr}_{2} \mathrm{O}_{3}$ & 0.006 & 0.005 & 0.007 & 0.005 \\
$\mathrm{Mn}_{2} \mathrm{O}_{3}$ & 0.012 & 0.013 & 0.022 & 0.025 \\
$\mathrm{ZnO}_{\mathrm{SrO}}$ & 0.004 & 0.004 & 0.005 & 0.004 \\
$\mathrm{LOI}\left(950{ }^{\circ} \mathrm{C}\right)$ & 15.85 & 20.69 & 27.53 & 17.20 \\
\hline
\end{tabular}

LOI loss on ignition

Fig. 4 XRD patterns of the diatomite samples of Ouled Djilali (Q: quartz, C: calcite, D: dolomite, A: alumina)

Table 4 Mineral phases (\%) of the Ouled Djilali diatomite samples samples make them interesting materials for adsorption in various.

\subsection{XRD analysis}

XRD analysis was performed on OD natural diatomite samples for mineralogical and chemical identifications, and the corresponding diagrams are shown in Fig. 4. Additionally, the X-ray detailed diffraction peaks information is listed in Table 4. Typical for all samples and more specifically for OD04 and OD08 materials, the specific shape of the obtained diffractograms and the high intensity of the background suggest a high mass quantity of $\mathrm{SiO}_{2}$ present as amorphous opal A phase whose reflections dominate in the corresponding XRD patterns between $19^{\circ}$ and $32^{\circ}$ ( 2 Theta), this finding being in accordance with the XRF results. A high content of crystalline phase and the most important reflections corresponding to calcite, dolomite, illite, and kaolinite phases are also observed (Table 4)

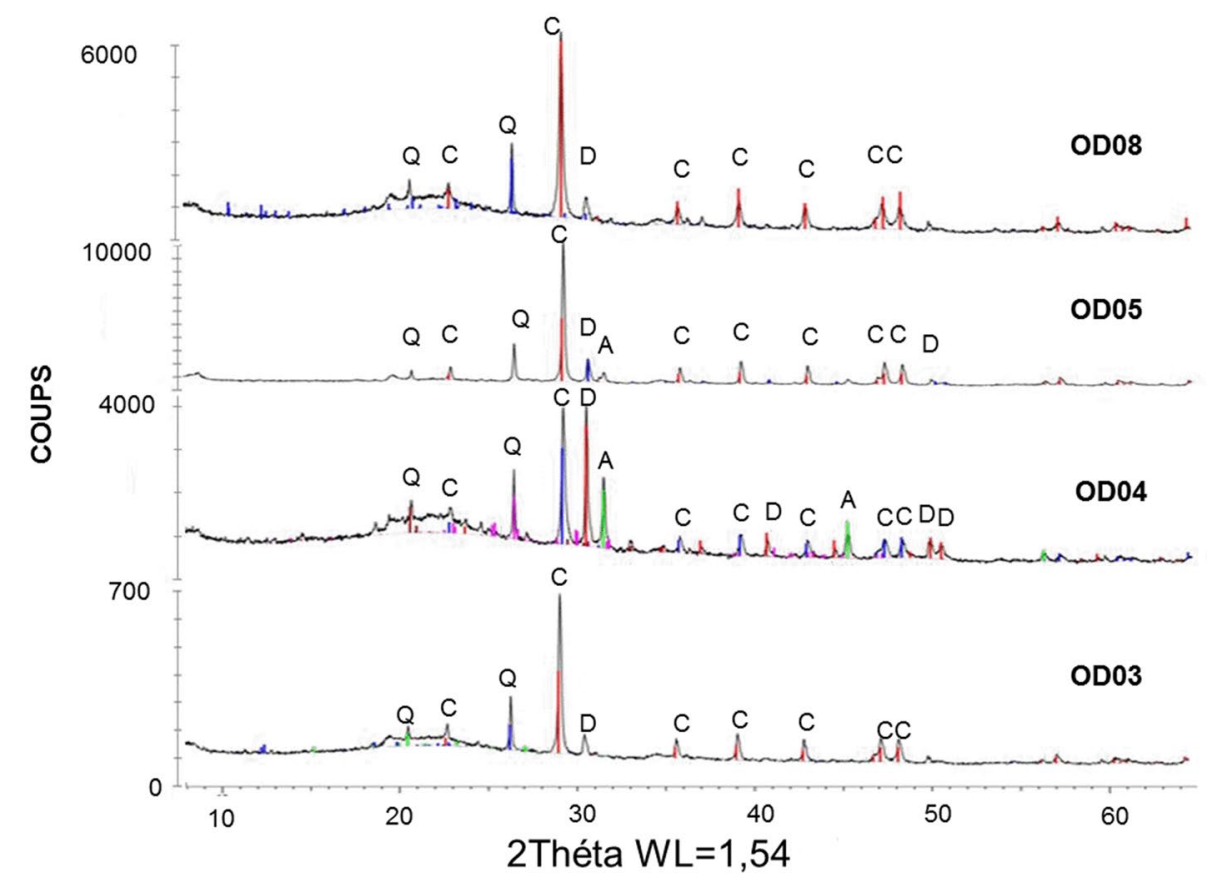

\begin{tabular}{llcllllll}
\hline Samples & Calcite & Dolomite & Quartz & Pyrite & Illite & Chlorite & Kaolinite & Albite \\
\hline OD03 & 47.54 & 6.66 & 7.03 & - & 19.26 & - & 13.82 & 5.69 \\
OD04 & 33.96 & 24.4 & 4.66 & 0.15 & 18.34 & 2.33 & 13.78 & 2.36 \\
OD05 & 55.72 & 8.69 & 6.61 & - & 20.25 & 1.81 & 4.78 & 2.13 \\
OD08 & 49.10 & 7.16 & 5.76 & - & 17.79 & - & 14.26 & 5.93 \\
\hline
\end{tabular}


revealing raw materials with irregular structures. The difference in impurities contents such as albite, chlorite, and pyrite also points to the different sedimentary environments of the diatomite samples.

\subsection{SEM analysis}

An insight was provided about the morphology and microstructure of the obtained OD diatomite samples by means of scanning electron microscopy (SEM) characterization. The microscopic pictures revealed the existence of intact diatomite skeletons whose framework structure is composed of diatomite shells represented by various diatom morphological types. The SEM observation clearly confirmed the presence of a well-defined and mostly preserved porous structure, which is an important parameter and key medium for any adsorption process, the porous shells consisting mainly of $\mathrm{SiO}_{2}$ groups $[27,28]$. It can be also inferred that the diatomite samples are rich in two classes of diatoms: centric and pennate, and large void volumes (Fig. 5a-c). Each frustule of diatom contains areolae due to its high porosity, and the size and disposition of these areolae vary with the species nature. The high porosity of the studied diatomite material was one of the main reasons for selecting it as a potential sorbent.

\subsection{Fourier transform infrared spectroscopy (FTIR)}

FTIR technique was used to confirm the presence of the functional groups of the diatomite before their use as dye adsorbent. The FTIR analyses spectra are gathered in Fig. 6 . There are no significant differences between the positions of the basic characteristic bands. Based upon reviewing the analysis data, the characteristic peaks of diatomite are clearly detected at 3435, 1426, 1070, 800 and $454 \mathrm{~cm}^{-1}$. The band at $3435 \mathrm{~cm}^{-1}$ is due to stretching vibration of the hydroxyl groups in physically adsorbed water molecules (silanol group SiO-H) [29-31], and this group is responsible for the adsorption process [32]. The carbonates IR band appears at $1426 \mathrm{~cm}^{-1}$ [33]. The rocking and asymmetric stretching vibration band of siloxane $(-\mathrm{Si}-\mathrm{O}-\mathrm{Si}-)$ in diatomite appears at wave numbers $1070 \mathrm{~cm}^{-1}[30,33,34]$. Other bands at 800 and $454 \mathrm{~cm}^{-1}$ are also characteristic of silica; the first one may be related to the stretching vibration of $\mathrm{Al}-\mathrm{O}-\mathrm{Si}$ [35], but it can be also attributed to $\mathrm{O}-\mathrm{H}$ deformation or the free silica and/or symmetric stretching in $\mathrm{SiO}-\mathrm{H}[31,36,37]$, whereas the second band is assigned to the bending vibrations of $\mathrm{Si}-\mathrm{O}-\mathrm{Si}$ [36].
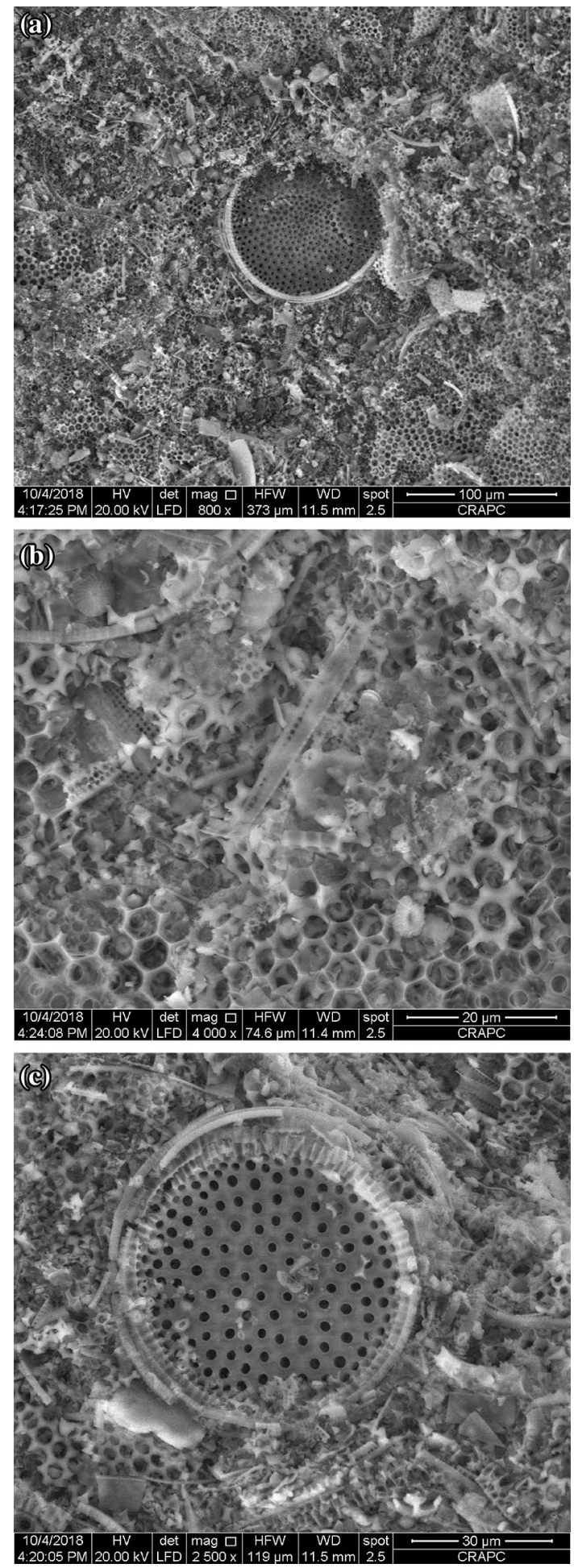

Fig. 5 a Morphology observed with SEM images of OD03 diatomite sample. b Morphology observed with SEM images of OD03 diatomite sample. c Morphology observed with SEM images of OD03 diatomite sample 
Fig. 6 FTIR spectra of the diatomite samples of Ouled Djilali

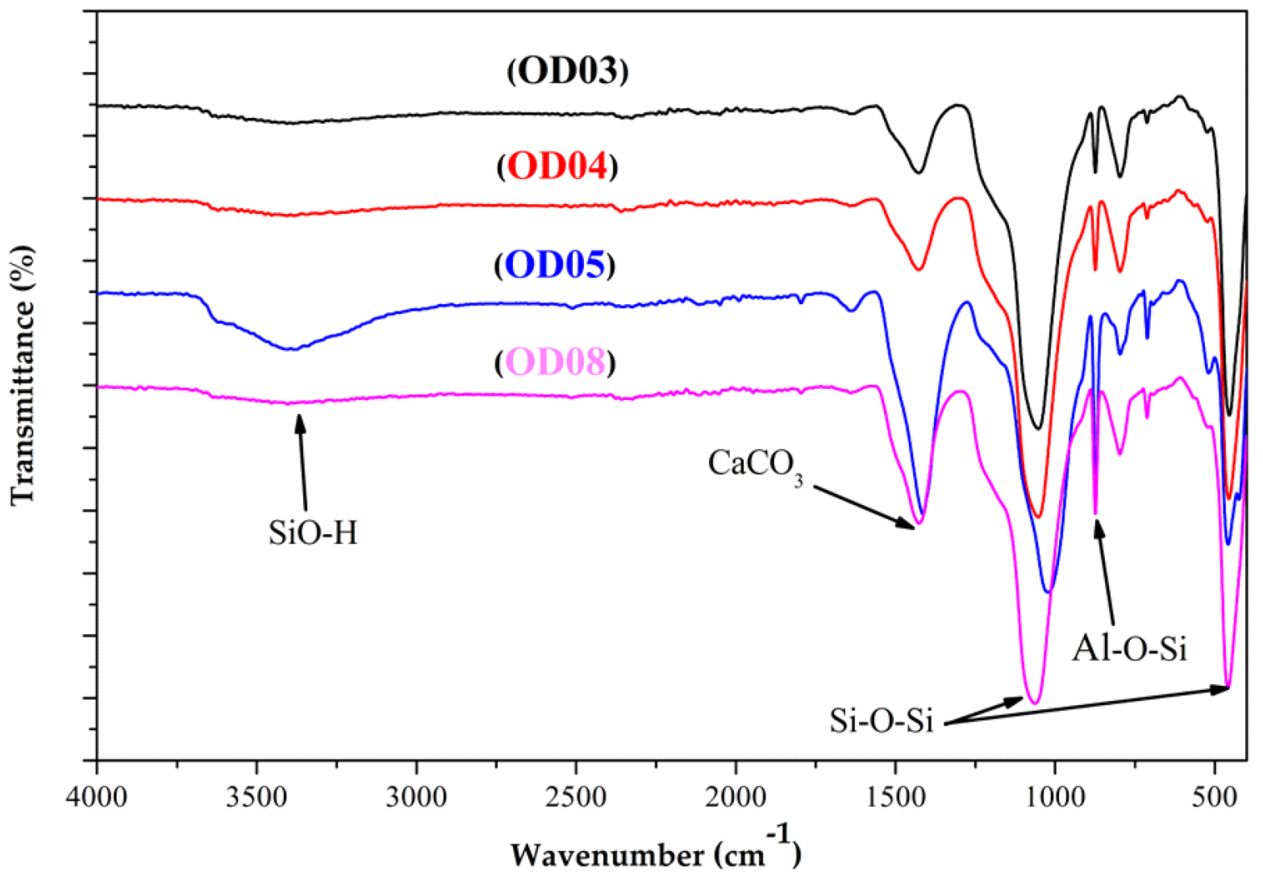

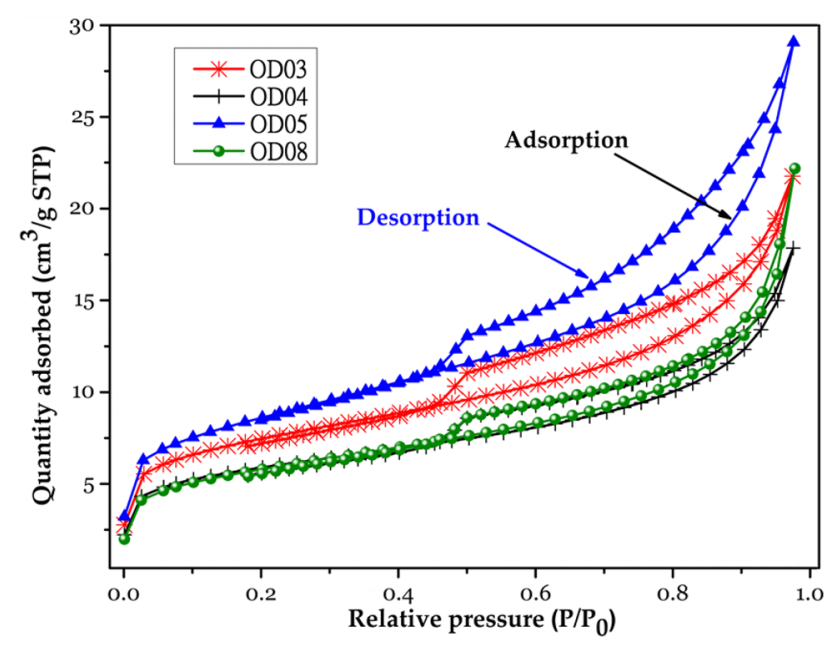

Fig. 7 Nitrogen adsorption-desorption isotherms of raw diatomite samples of Ouled Djilali
Considering these functional groups on the surface of the diatomite witch facilitate the electrostatic attraction with the cationic $\mathrm{MB}$, it is proposed that hydrogen bond would be formed between the raw diatomite and $\mathrm{MB}$ and contributes significantly to the high adsorption of dye [27].

\section{6 $\mathrm{N}_{2}$-sorption study}

The $\mathrm{N}_{2}$ adsorption-desorption isotherms of the studied OD diatomite at liquid nitrogen temperature are provided in Fig. 7. BET and external surface areas as well as pore volumes of the diatomite samples calculated on the basis of these isotherms are summarized in Table 5. As shown in Fig. 7, all the raw OD diatomite samples present the same Type IV nitrogen adsorption-desorption isotherm shape, exhibiting a characteristic feature as type II isotherms in addition to a steep uptake at $\mathrm{P} / \mathrm{P}_{\mathrm{o}}$ of above 0.8 which can be assigned to the existence of macropores in the raw
Table 5 Textural parameters of the natural diatomite samples of Ouled Djilali

\begin{tabular}{llllll}
\hline Samples & $\mathrm{V}_{\mathrm{t}}\left(\mathrm{cm}^{3} / \mathrm{g}\right)$ NTU & $\mathrm{V}_{\text {mes }}\left(\mathrm{cm}^{3} / \mathrm{g}\right)$ & $\mathrm{V}_{\text {mic }}\left(\mathrm{cm}^{3} / \mathrm{g}\right)$ & $\mathrm{S}_{\text {BET }}\left(\mathrm{m}^{2} / \mathrm{g}\right)$ & $\mathrm{S}_{\text {ext }}\left(\mathrm{m}^{2} / \mathrm{g}\right)$ \\
\hline OD03 & 0.034 & 0.028 & 0.006 & 58.87 & 3.99 \\
OD04 & 0.028 & 0.023 & 0.005 & 45.28 & 2.98 \\
OD05 & 0.045 & 0.040 & 0.005 & 69.95 & 5.38 \\
OD08 & 0.034 & 0.030 & 0.004 & 47.91 & 3.31 \\
\hline
\end{tabular}

$\mathrm{V}_{\mathrm{t}^{\prime}}$ total pores volume; $\mathrm{V}_{\text {mes' }}$ mesoporous volume, $\mathrm{V}_{\text {mic }}$ microporous volume, $\mathrm{S}_{\mathrm{BET}}, \mathrm{BET}$ area, $\mathrm{S}_{\text {ext' }}$, external surface area 
Table 6 Physicochemical and textural characteristics of diatomite materials

\begin{tabular}{|c|c|c|c|c|c|c|c|}
\hline Diatomite from & $\mathrm{SiO} 2 \%$ & $\mathrm{CaO} \%$ & $\mathrm{~S}_{\mathrm{BET}}\left(\mathrm{m}^{2} / \mathrm{g}\right)$ & $\mathrm{V}_{\text {total }}\left(\mathrm{cm}^{3} / \mathrm{g}\right)$ & $V_{\text {micro }}\left(\mathrm{cm}^{3} / \mathrm{g}\right)$ & $\mathrm{pH}$ & References \\
\hline Egypt (Kom Osheam) & 74.20 & 10.58 & $10-30$ & - & - & $7.0-8.0$ & [39] \\
\hline Awinate (Morocco) & 87.71 & 0.4 & 22.7 & - & - & 7 & {$[40]$} \\
\hline Ras Traf, Rif (Morocco) & 72.8 & 5.86 & 21 & 0.035 & 0.0024 & - & [41] \\
\hline Jordan & 72 & 1.48 & 27.80 & & & & {$[42]$} \\
\hline Egypt (Masakheet) & 61.65 & 21.27 & & & & & {$[43]$} \\
\hline Sig (Mascara- Algeria) & 67.3 & 19.5 & 22 & 1.4 & - & 7.9 & {$[16]$} \\
\hline Ouled Djilali & $32.8-61.52$ & $13.8-25.9$ & $45.28-69.95$ & $0.028-0.045$ & $0.004-0.006$ & $7.82-8.14$ & In this study \\
\hline
\end{tabular}

$\mathrm{V}_{\mathrm{t}}$, total pores volume; $\mathrm{V}_{\text {mic }}$, microporous volume; $\mathrm{S}_{\mathrm{BET}}, \mathrm{BET}$ specific surface area

Table 7 Physicochemical properties of natural diatomite samples of Ouled Djilali

\begin{tabular}{lllllll}
\hline Samples & $\mathrm{pH}$ & $\begin{array}{l}\mathrm{da}\left({ }^{*}\right) \\
\mathrm{g} \cdot \mathrm{cm}^{-3}\end{array}$ & $\begin{array}{l}\mathrm{H} \\
(\%)\end{array}$ & $\begin{array}{l}\text { Ads } \mathrm{H}_{2} \mathrm{O} \\
(\%)\end{array}$ & $\begin{array}{l}\text { Ads Oils } \\
(\%)\end{array}$ & $\begin{array}{l}\text { Chlorides } \\
(\%)\end{array}$ \\
\hline OD03 & 8.01 & 0.48 & 97.20 & 37.82 & 63.85 & 0.209 \\
OD04 & 7.99 & 0.42 & 96.60 & 45.45 & 62.77 & 0.105 \\
OD05 & 7.82 & 0.64 & 90.46 & 15.89 & 98.31 & 2.144 \\
OD08 & 8.14 & 0.49 & 96.35 & 32.33 & 62.88 & 0.248 \\
\hline
\end{tabular}

${ }^{*}$ ) da: bulk density material. By comparing the different samples of OD diatomite, it is obvious that the OD05 has the larger BET surface area value $\left(69.95 \mathrm{~m}^{2} \mathrm{~g}^{-1}\right)$, which was expected to enhance the adsorption performance [38]. Besides, the Ouled Djilali diatomite $\left(47.91-69.95 \mathrm{~m}^{2} / \mathrm{g}\right)$ exhibits a higher $\mathrm{S}_{\mathrm{BET}}$ surface area value when compared to other diatomite materials from the literature, as shown in Table 6, and can be considered as a potential adsorbent for pollutants removal from wastewater, and environmental remediation.

\subsection{Physicochemical tests}

The following physical properties of OD diatomite samples have been determined in terms of apparent density (da); humidity $(\mathrm{H})$, water and oil absorption (Ads $\mathrm{H}_{2} \mathrm{O}$, Ads Oils), and chlorides percentage. The corresponding results are summarized in Table 7.

Based on the above results, the bulk density values range from 0.42 to $0.64 \mathrm{~g} / \mathrm{cm}^{3}$. Water absorption values are between 15.89 and $45.45 \%$, and the oils absorption values vary from 62.77 to $98.13 \%$. The OD04 sample has the highest average water absorption, and the lowest bulk density (light-colored diatomite). However, the darkestcolored diatomite (OD05, OD08) has the lowest water absorption and highest bulk density. The two parameters show reversely proportional dependence [42]. In contrast, the values of oil absorption and the bulk density show proportional dependence.

The $\mathrm{pH}$ of the diatomite aqueous suspensions lies between 7.82 and 8.14 , which may be related to the presence of alkaline oxides in the diatomite samples providing a neutral or slightly alkaline reaction of their aqueous suspensions [39].

\subsection{Discoloration capacity}

After examining the textural, structural and physicochemical properties of the OD diatomite powders, which significantly affect their behavior in environmental applications, these samples were subjected to a discoloration study in order to evaluate their adsorption performance by means of methylene blue (MB) dye ions recovery tests from aqueous solution, and to explore the adsorbent-adsorbate interactions. Adsorption isotherm (Fig. 8) was obtained by varying the $\mathrm{MB}$ initial concentration at a fixed temperature $\left(25^{\circ} \mathrm{C}\right)$, with maintaining a constant dose of adsorbent, the solid/liquid ratio kept at $2.0 \mathrm{~g} / \mathrm{L}$. The adsorption isotherm was categorized as an L-shape according to the Giles et al. classification [44] which suggests that the studied OD diatomite samples exhibit a high adsorption affinity toward the MB dye in solution without major competition from water molecules for the solid active sites [45]. The nonlinear forms of Langmuir, Freundlich, Sips and Temkin models were used to more interpret the obtained data and to make it easier to understand the adsorption mechanism (Fig. 8a-d). According to the isotherm constants and parameters presented in Table 8 , it can be noticed that the Langmuir and Sips equations are more suitable than the Freundlich and Temkin equations for the adsorption system studied in this work. The finding regarding the 

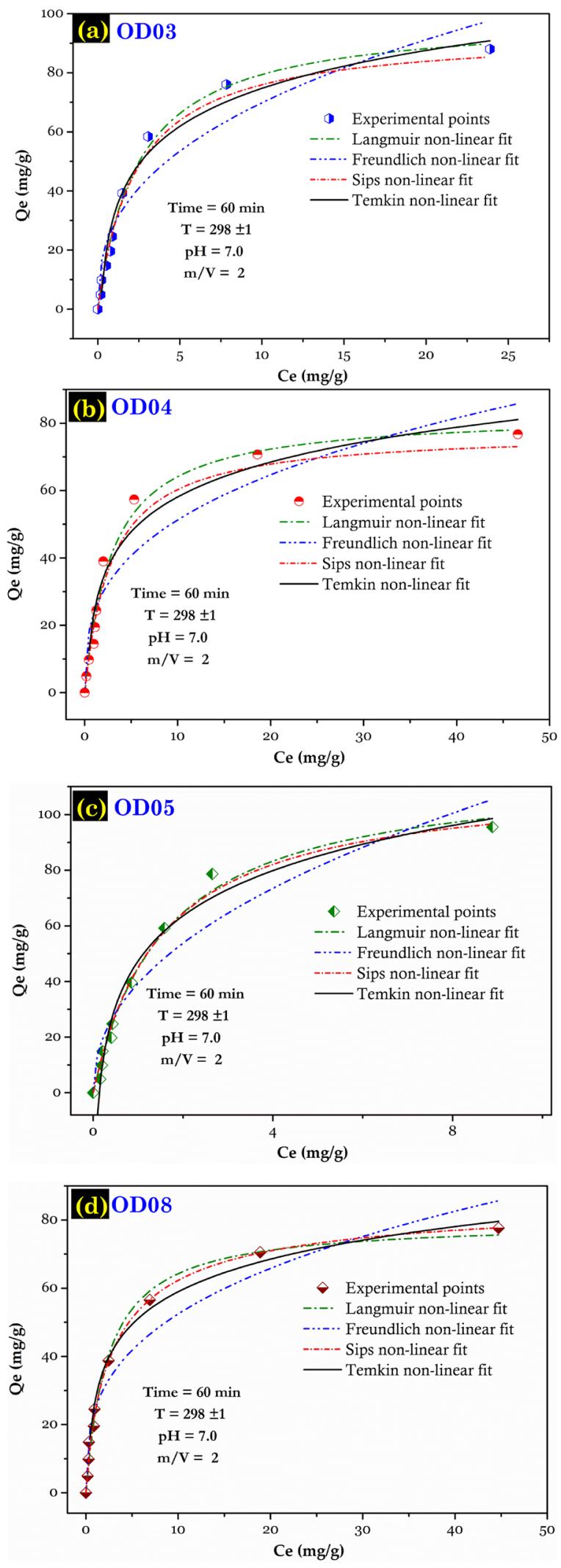

Fig. 8 Adsorption isotherm of MB onto Ouled Djilali diatomite samples (experimental conditions: $\mathrm{C}_{\mathrm{o}}=10-200 \mathrm{mg} / \mathrm{L}, \mathrm{pH}=7.0$, $\mathrm{m} / \mathrm{V}=2.0 \mathrm{~g} / \mathrm{L}$, and $\mathrm{t}=60 \mathrm{~min}, \mathrm{~T}=25^{\circ} \mathrm{C}$ )
Langmuir fitting can be attributed to the homogenous distribution of active sites on the diatomite surface [46]. This suggests that the adsorption process of MB dye onto diatomite surfaces is favorable and monolayer in nature over the whole range of tested concentrations, induced by homogeneous solid surface energy along with no interaction between adsorbed species.

From the Langmuir model, a reasonably good maximum adsorption capacity of the studied OD diatomite samples was obtained ranging between 79.66 and $116.59 \mathrm{mg} / \mathrm{g}$. As expected, OD05 sample exhibited the higher $Q_{\text {max }}^{\circ}(116.59 \mathrm{mg} / \mathrm{g})$ value than the other Ouled Djilali diatomite adsorbents. Obviously, adsorption efficiency is greatly related to $S_{B E T}$ and to the total volume registered values (Table 5), whereas the enhancement of these two parameters contributes to the enhancement of the adsorption capacity of the MB dye [28].

As diatomite is a natural material, it must be compared with other natural materials such as zeolite, phosphor, gypsum, clay, and other siliceous adsorbents. Table 9 shows the comparison of the adsorption capacities of some adsorbents. It is clear from the comparison that the OD05 $(116.59 \mathrm{mg} / \mathrm{g})$ possesses a higher adsorption capacity than other reported adsorbents, after the Jordanian diatomite $(198 \mathrm{mg} / \mathrm{g})$. This is probably due to the fact that the diatomite surface can interact with MB in different ways; (1) electrostatic attraction, (2) chemical adsorption via conjugation, hydrogen bonding, and pore filling mechanism [27]. It seems that the amount of MB dye loaded on the diatomite surface depends on the nature of the surface (determined by the mentioned method: FTIR, SEM, BET), which varies from a sample to another $\left(S_{\mathrm{BET}}, V_{\mathrm{t}}\right.$, and the silica percentage).

\section{Conclusions and suggestions}

In this study, representative raw diatomite samples were collected from Ouled Djilali (OD), Mostaganem (Lower Chelif basin, Algeria northwestern), and subjected to characterization by several methods. Results show that the silica $\left(\mathrm{SiO}_{2}\right)$ constitutes the major component of the OD diatomite with a significant amount of carbonate $(\mathrm{CaO})$ beside other minor constituents.

As crystalline phases, were obtained the main accompanied minerals: calcite, dolomite, illite, and kaolinite, with less important presence of pyrite, chlorite, and albite. An interesting texture with relatively good surface area and pore volume was estimated for the studied diatomite products, along with a porous framework structure rich in intact diatom frustules (centric and pennate forms). All samples showed a high sorption capacity for oils and water. 
Table 8 Parameters of adsorption equilibrium isotherms of MB dye onto diatomite samples

\begin{tabular}{|c|c|c|c|c|c|c|c|c|c|}
\hline \multirow[t]{2}{*}{ Model } & \multirow[t]{2}{*}{ Unit } & \multicolumn{2}{|l|}{ OD03 } & \multicolumn{2}{|l|}{ OD04 } & \multicolumn{2}{|l|}{ OD05 } & \multicolumn{2}{|l|}{ OD08 } \\
\hline & & Value & SD & Value & SD & Value & SD & Value & SD \\
\hline \multicolumn{10}{|c|}{ Langmuir } \\
\hline$Q_{\text {max }}^{\circ}$ & $\mathrm{mg} / \mathrm{g}$ & 99.12 & 2.845 & 82.91 & 3.202 & 116.59 & 5.388 & 79.66 & 2.265 \\
\hline$K_{\mathrm{L}}$ & $\mathrm{L} / \mathrm{mg}$ & 0.404 & 0.032 & 0.342 & 0.041 & 0.625 & 0.071 & 0.418 & 0.042 \\
\hline$R^{2}$ & - & 0.994 & - & 0.984 & - & 0.988 & - & 0.991 & - \\
\hline$\chi^{2}$ & - & 6.078 & - & 12.01 & - & 12.47 & - & 6.803 & - \\
\hline \multicolumn{10}{|c|}{ Freundlich } \\
\hline$K_{\mathrm{F}}$ & $(\mathrm{mg} / \mathrm{g}) /(\mathrm{mg} / \mathrm{L})^{\mathrm{n}}$ & 28.78 & 3.688 & 23.75 & 3.652 & 39.34 & 3.981 & 24.68 & 2.742 \\
\hline$n$ & - & 0.385 & 0.052 & 0.334 & 0.051 & 0.451 & 0.059 & 0.327 & 0.037 \\
\hline$R^{2}$ & - & 0.904 & - & 0.883 & - & 0.905 & - & 0.939 & - \\
\hline$\chi^{2}$ & - & 90.96 & - & 90.49 & - & 102.33 & - & 47.12 & - \\
\hline \multicolumn{10}{|l|}{ Sips } \\
\hline$Q_{\max }$ & $\mathrm{mg} / \mathrm{g}$ & 93.66 & 6.499 & 77.57 & 7.116 & 112.99 & 10.161 & 86.49 & 4.049 \\
\hline$K_{\mathrm{s}}$ & $\mathrm{L} / \mathrm{mg}$ & 0.429 & 0.057 & 0.349 & 0.061 & 0.665 & 0.132 & 0.386 & 0.034 \\
\hline$R^{2}$ & - & 0.988 & - & 0.971 & - & 0.986 & - & 0.995 & - \\
\hline$\chi^{2}$ & - & 11.68 & - & 22.38 & - & 15.14 & - & 4.03 & - \\
\hline \multicolumn{10}{|c|}{ Temkin } \\
\hline$K_{\mathrm{T}}$ & $\mathrm{L} / \mathrm{mg}$ & 5.644 & 0.912 & 4.932 & 1.175 & 7.557 & 0.795 & 7.223 & 0.877 \\
\hline$\Delta Q$ & $\mathrm{KJ} / \mathrm{mol}$ & 133.71 & 8.595 & 166.20 & 13.471 & 105.73 & 5.339 & 179.81 & 6.944 \\
\hline$R^{2}$ & - & 0.969 & - & 0.951 & - & 0.981 & - & 0.989 & - \\
\hline$\chi^{2}$ & - & 28.99 & - & 37.53 & - & 20.64 & - & 8.54 & - \\
\hline
\end{tabular}

SD, standard deviation

Table 9 Comparison of Langmuir maxima adsorption capacity $\left(\mathrm{Q}_{\max }^{\circ}\right)$ of MB dye

\begin{tabular}{|c|c|c|c|c|c|c|c|c|}
\hline & \multicolumn{2}{|c|}{ Textural properties } & \multicolumn{4}{|c|}{ Adsorption isotherm condition } & \multirow[t]{2}{*}{$Q_{\text {max }}^{\circ}(\mathrm{mg} / \mathrm{g})$} & \multirow[t]{2}{*}{ References } \\
\hline & $\mathrm{S}_{\mathrm{BET}}\left(\mathrm{m}^{2} / \mathrm{g}\right)$ & $V_{\text {total }}\left(\mathrm{cm}^{3} / \mathrm{g}\right)$ & $\mathrm{pH}$ & Time (h) & $C_{\mathrm{o}}(\mathrm{mg} / \mathrm{L})$ range & $T\left({ }^{\circ} \mathrm{C}\right)$ & & \\
\hline DT (OD05) & 69.95 & 0.045 & 7 & 1 & $10-200$ & 25 & 116.59 & This study \\
\hline Jordanian DT & 27.80 & & 11 & 48 & $100-1000$ & 20 & 198 & {$[42]$} \\
\hline Egyptian DT (Masakheet) & - & - & 8 & 2 & $60-200$ & 25 & 104.797 & [43] \\
\hline Marocco diatomite & 22.7 & - & 7 & 0.3 & 8 & RT & 10.57 & {$[40]$} \\
\hline $\begin{array}{l}\text { Beer brewery waste (DT waste, } \\
\text { Celite Co., USA) }\end{array}$ & 4.522 & 0.0317 & 7 & 24 & $0.5-2.5$ & 25 & 4.92 & [47] \\
\hline DT (Celite Co., USA) & 2.133 & 0.0045 & 7 & 24 & $0.5-2.5$ & 25 & 1.80 & [47] \\
\hline Natural clay & 30.0 & - & 5.65 & 1 & $10-100$ & 20 & 58.2 & [48] \\
\hline Ghassoul (Morocco) & - & - & $4.5-5$ & 2 & $100-600$ & 25 & 294 & {$[46]$} \\
\hline Kaolin (India) & - & - & - & 3 & $10-25$ & 27 & 13.99 & [49] \\
\hline Unmodified Zeolite & & & 6.85 & 1 & $5-55$ & 25 & 8.67 & {$[50]$} \\
\hline Raw clay (Benguerir, Marocco) & - & - & 6.5 & 0.5 & $10-80$ & 25 & 30 & {$[51]$} \\
\hline Phosphate naturel (Marocco) & - & - & - & 3 & - & 25 & 7.46 & {$[52]$} \\
\hline Gypsum & 5.67 & & 7.5 & 1.5 & $5-25$ & 25 & 36 & [53] \\
\hline
\end{tabular}

RT, room temperature; DT, diatomite 
When applied as an adsorbent for the methylene blue (MB) dye removal study, OD diatomite samples displayed good adsorption ability, evidencing good interactions between with MB dye adsorbate. The isotherm data fitted well the Langmuir model, and the calculated adsorption capacity of MB dye reached $116.59 \mathrm{mg} / \mathrm{g}(\mathrm{OD} 05)$ at $25^{\circ} \mathrm{C}$ and $\mathrm{pH}$ 7.0. The obtained performances were comparable to those regarding several interesting materials reported in the literature.

These preliminary findings highlighted the potential use of the studied Ouled Djilali diatomite as promising low-cost and ecofriendly adsorbent for dyes separation from wastewater containing toxic contaminants. A conclusion can be also stated about the variation in diatomite characteristics, in the same deposit, with the variation in the geological layer or depth, fact which has to consider the suitable destination to choose for any industrial application.

Acknowledgements Authors would like to thank the "Ecole Nationale Supérieure des Sciences de la Mer et de l'Aménagement du Littoral" (ENSSMAL) laboratories and the "Centre de Recherche scientifique et technique en Analyses Physico-Chimiques » (CRAPC) for their cooperative support. We sincerely would like to extend our acknowledgments to the editors and the reviewers for their careful review contributing to improving the quality of this paper.

\section{Compliance with ethical standards}

Conflict of interest The authors declare that they have no conflict of interest.

Open Access This article is licensed under a Creative Commons Attribution 4.0 International License, which permits use, sharing, adaptation, distribution and reproduction in any medium or format, as long as you give appropriate credit to the original author(s) and the source, provide a link to the Creative Commons licence, and indicate if changes were made. The images or other third party material in this article are included in the article's Creative Commons licence, unless indicated otherwise in a credit line to the material. If material is not included in the article's Creative Commons licence and your intended use is not permitted by statutory regulation or exceeds the permitted use, you will need to obtain permission directly from the copyright holder. To view a copy of this licence, visit http://creativecommons. org/licenses/by/4.0/.

\section{References}

1. Ma L, Chen Q, Zhu J, Xi Y, He H, Zhu R, Tao Q, Ayoko GA (2016) Adsorption of phenol and Cu (II) onto cationic and zwitterionic surfactant modified montmorillonite in single and binary systems. Chem Eng J 283:880-888. https://doi.org/10.1016/j.cej. 2015.08.009

2. Akti $F$ (2018) Photocatalytic degradation of remazol yellow using polyaniline-doped tin oxide hybrid photocatalysts with diatomite support. Appl Surf Sci 455:931-939. https://doi.org/ 10.1016/j.apsusc.2018.06.019
3. Namasivayam C, Prabha D, Kumutha M (1998) Removal of direct red and acid brillant blue by adsorption onto banana pith. Bioresour Technol 64:77-79

4. Sharma YC, Upadhyay Uma SN, Gode F (2009) Adsorptive removal of a basic dye from water and wastewater by activated carbon. J appl Sci in Environ Sanit 4(1):21-28

5. Lin SH, Juang RS (2009) Adsorption of phenol and its derivatives from water using synthetic resins and low-cost natural adsorbents: a review. J Environ Manag 90:1336-1349. https://doi.org/ 10.1016/j.jenvman.2008.09.003

6. Yu F, Ma J, Wang J, Zhang M, Zheng J (2016) Magnetic iron oxide nanoparticles functionalized multi-walled carbon nanotubes for toluene, ethylbenzene and xylene removal from aqueous solution. J Chemoph. https://doi.org/10.1016/j.chemosphere.2015. 12.018

7. Cheng WP, Gao W, Cui X, Ma JH, Li RF (2016) Phenol adsorption equilibrium and kinetics on zeolite $\mathrm{X} /$ activated carbon composite. J Taiwan Inst Chem Eng 000(2016):1-7. https://doi.org/10. 1016/j.jtice.2016.02.004

8. Ouakouak A, Rihani K, Youcef L, Hamdi N, Guergazi S (2020) Adsorption characteristics of $\mathrm{Cu}$ (II) onto $\mathrm{CaCl}_{2}$ pretreated Algerian bentonite. Mater Res Exp. https://doi.org/10.1088/ 2053-1591/ab5ee4

9. Sarioglu M, Atay UA (2006) Removal of methylene blue by using biosolid. Global NEST J 8(2):113-120

10. Tahir H, Sultan M, Jahanzeb Q (2008) Removal of basic dye methylene blue by using bioabsorbents Ulva lactucaand Sargassum. Afr J Biotechnol 7(15):2649-2655

11. Gupta VK, Mohan D, Sharma S, Sharma M (2000) Utilization of Bagasse Fly Ash ( a sugar industry waste) for the removal of copper and zinc from wastewater. Sep Purif Technol 18:131-140

12. Benaïssa $\mathrm{H}$. (2008) Effect of $\mathrm{pH}$ on the removal of methylene blue from synthetic aqueous solution by a natural waste material: almond pee. Sci Stud Res IX(2), ISSN 1582-540X.

13. Bessedik M, Belkebir L, Mansour B (2002) Révision de l'âge miocène inférieur (au sens des anciens auteurs) des dépôts du bassin du Bas Chélif (Oran, Algérie): conséquences biostratigraphiques et géodynamiques. Mémo Serv géolog d'Algérie 11:167-186

14. Mansour B, Bessedik M, Saint Martin J-P, Belkebir L (2008) Signification paléoécologique des assemblages de diatomées du Messinien du Dahra sud-occidental (bassin du Chélif, Algérie nord-occidentale). Geodiversity 30(1): 117-139 (annexes available on: www.geodiversitas.com ).

15. Moret $L$ (ed) (1964) Manuel de paléontologie végétale. Masson et $\mathrm{Cie}$, Paris

16. Hamdi B (1998) Etude physico-chimique de la surface des diatomites, Thèse de doctorat d'état en science .U.S.T.H.B, Algérie

17. He Y, Jiang DB, Jiang DY, Chena J, Zhang YX (2018) Evaluation of $\mathrm{MnO}_{2}$-templated iron oxide-coated diatomites for their catalytic performance in heterogeneous photo Fenton-like system. J Hazard Mater 344:230-240

18. Wang $Z$, Lin $Y$, Wu D, Kong $H$ (2016) Hydrous iron oxide modified diatomite as an active filtration medium for phosphate capture. Chemosph 144:1290-1298

19. Rabbani M, Rafiee F, Ghafuri H, Rahimi R (2016) Synthesis of Fe3O4 nonoparticles via a fast and facile mechanochemicl method: modification of surface with porphyrin and photocatalytic study. Mater Lett 166: 247-250. Doi: https://doi.org/ 10.1016/j.matlet.2015.12.087

20. Barbosa IA, Zanatta LD, Espimpolo DM, Silva DL, Nascimento LF, Zanardi FB, Sousa Filho PC, Serra OA, lamamoto Y (2017) Magnetic diatomite (Kieselguhr) $/ \mathrm{Fe}_{2} \mathrm{O}_{3} / \mathrm{TiO}_{2}$ composite as an efficient photo-Fenton system for dye degradation. Solid State Sci 72(2017):14-20 
21. Rouchy JM, Caruso A, Pierre C, Blanc-Valleron MM, Bassetti MA (2007) The end of the Messinian salinity crisis: evidences from the Chelif Basin (Algeria). Palaeogeogr Palaeoclimatol Palaeoecol 254:386-417

22. Perrodon $A$ (1957) Etude géologique des bassins néogènes sublittoraux de l'Algérie occidentale. Pub. Serv. Carte géol. Algérie, n. s. Alger, Bull. 12,382p.

23. Langmuir I (1918) The adsorption of gases on plane surfaces of glass, mica and platinum. J Am Chem Soc 40(1918):1361-1367

24. Freundlich HMF (1906) Uber die adsorption in losungen. Z Phys Chem (Leipzig) 571:385-470

25. Sips R (1948) The structure of a catalyst surface. J Chem Phys 16:490-495

26. Temkin M.I. (1941) Adsorption equilibrium and the kinetics of processes on nonhomogeneous surfaces and in the interaction between adsorbed molecules. Russian J Phys Chem (USSR) 15:296-332

27. Eltaweil AS, Elshishini HM, Ghatass ZF, Elsubruiti GM (2020) (2020) Ultra-high adsorption capacity and selective removal of Congo red over aminated graphene oxide modified $\mathrm{Mn}$-doped UiO-66 MOF. Powder Technol. https://doi.org/10.1016/j.powtec. 2020.10.084

28. Eltaweil AS, Elgarhy GS, El-Subruiti GM, Omer AM (2020) Carboxymethyl cellulose/carboxylated graphene oxide composite microbeads for efficient adsorption of cationic methylene blue dye. Int J Biol Macromol 154:307-318

29. Fu X, Liu Z, Wu B, Wang J, Lei J (2016) Preparation and thermal properties of stearic acid/diatomite composites as form-stable phase change materials for thermal energy storage via direct impregnation method. J Therm Anal Calorim 123:1173-1181. https://doi.org/10.1007/s10973-015-5030-1

30. Yuan P, Wu DQ, He HP, Lin ZY (2003) The hydroxyl species and acid sites on diatomite surface: a combined IR and Raman study. Appl Surf Sci 227:30-39. https://doi.org/10.1016/j.apsusc.2003. 10.031

31. Inchaurrondo N, Font J, Ramos CP, Haur P (2016) Natural diatomite: efficient green catalyst for Fenton-like oxidation of Orange II. Appl Catal B Environ 181:481-494. https://doi.org/10.1016/j. apcatb.2015.08.022

32. Badii K, Ardejani FD, Sabri MA, Limaee NY, Shafaei SZ (2010) Adsorption of acid blue 25 dye on diatomite in aqueous solution. Indian J Chem Technol 17:7-10

33. Benkacem T, Hamdi B, Chamayou A, Balard H, Calvet R (2016) Physicochemical characterization of a diatomaceous upon an acid treatment: a focus on surface properties by inverse gas chromatography. Powder Technol 294(2016):498-507. https:// doi.org/10.1016/j.powtec.2016.03.006

34. Zhang S, Cui M, Zhang Y, Yu Z, Meng C (2016) Synthesis of zeolite $Y$ from diatomite and its modification by dimethylglyoxime for the removal of $\mathrm{Ni}$ (II) from aqueous solution. J Sol-Gel Sci Technol 80:215-225. https://doi.org/10.1007/s10971-016-4080-6

35. Vassileva P, Gentscheva G, Ivanova E, Tzvetkova P, Voykova D, Apostolova M (2011) Characterization of natural diatomites from Bulgaria. Compt Rend Acad Bulg Sci 64-N06-2011. https:// www.researchgate.net/publication/280577650.

36. Yu ZH, Zhang YF, Zhai SR, Wang Y, Pan YZ, Meng CG (2015) Amino-modified mesoporous sorbents for efficient Cd (II) adsorption prepared using non-chemical diatomite as precursor. J Sol-Gel Sci Technol 78:110-119. https://doi.org/10.1007/ s10971-015-3933-8

37. Khraisheh MAM, Al-degs YS, Mcminn WAM (2004) Remediation of wastewater containing heavy metals using raw and modified diatomite. Chem Eng J 99:177-184
38. Eltaweil AS, Ali Mohamed H, Abd El Monaem EM, El Subruiti GM (2020) Mesoporous magnetic biochar composite for enhanced adsorption of malachite green dye: characterization, adsorption kinetics, thermodynamics and isotherms. Adv Powder Technol. doi: https://doi.org/10.1016/j.apt.2020.01.005

39. Ibrahim S-S, Selim A-Q (2010) Producing a micro-porous diatomite by a simple classification calcination process. J Ore dress 12(23):24-32

40. Ababou N, Meziane D, Kherbeche A, Chaqroune A (2002) Etude de l'adsorption de colorants textiles sur une diatomite marocaine. Phys Chem News 6:130-134

41. Zaitan H, Feronnato C, Bianchi D, Achak O, Chafik T (2006) Etude des propriétés texturales et adsorbantes d'une diatomite marocaine: Application au traitement D'air chargé d'un polluant de type composé organique volatil. Annal Chim Sci Matér 31(2):183-196

42. Al-Ghouti MA, Khraisheh MAM, Allen SJ, Ahmad MN (2003) The removal of dyes from textile wastewater: a study of the physical characteristics and adsorption mechanisms of diatomaceous earth. J Environ Manag 69:229-238

43. Mohamed EA, Selim AQ, Zayed AM, Komarneni S, Mobarak M, Seliem MK (2018) Enhancing adsorption capacity of Egyptian diatomaceous earth by thermo-chemical purification: methylene blue uptake. J Colloid Interface Sci 534:408-419. https://doi. org/10.1016/j.jcis.2018.09.024

44. Giles $\mathrm{CH}$, Smith $D$, Huitson A (1974) A general treatment and classification of the solute adsorption isotherm I. Theoretical. J Colloid Interface Sci 47(3):755-765

45. Fröhlich AC, Ocampo-Pérez R, Diaz-Blancas V, Salau NPG, Dotto GL (2020) Three-dimensional mass transfer modeling of ibuprofen adsorption on activated carbon prepared by sonication. Chem Eng J 341:65-74. https://doi.org/10.1016/j.cej.2018.02. 020

46. Elass K, Laachach A, Alaoui A, Azzi M (2010) Removal of methylene blue from aqueous solution using ghassoul, a low-cost adsorbent. Appl Ecol Environ Res 8(2):153-163

47. Tsai W-T, Hsu H-C, Su T-Y, Lin K-Y, Lin C-M (2008) Removal of basic dye (methylene blue) from wastewaters utilizing beer brewery waste. J Hazard Mater 154:73-78

48. Gürses A, Doğar Ç, Yalçın $M$, Açıkyıldız M, Bayrak R, Karaca $S$ (2006) The adsorption kinetics of the cationic dye, methylene blue, onto clay. J Hazard Mater B 131:217-228.

49. Ghosh D, Bhattacharyya K-G (2002) Adsorption of methylene blue on kaolinite. Appl Clay Sci 20:295-300

50. Jin X, Jiang M, Shan X, Pei Z, Chen Z (2008) Adsorption of methylene blue and orange II onto unmodified and surfactant-modified zeolite. J Colloid Interface Sci 328:243-247

51. Allam K, Gourai K, El Bouari A, Belhorma B, Bih L (2018) Adsorption of Methylene Blue on raw and activated Clay: case study of Bengurir clay. J Mater Environ Sci 9(6):1750-1761. https://doi. org/10.26872/jmes.2018.9.6.195

52. Barka N, Nounah A, Assabbane A, Aîtichou Y (2006) Evaluation du pouvoir adsorbant du phosphate naturel dans le traitement des rejets textiles: comparaison avec le charbon actif. Proc Covaphos II 4:195-203

53. Muhammad AR, Shehadeh I, Ahmed A, Al-Zamly A (2009) Removal of methylene blue from aqueous solution by using gypsum as a low cost adsorbent. World Acad Sci Eng Technol 55:608-613

Publisher's Note Springer Nature remains neutral with regard to jurisdictional claims in published maps and institutional affiliations. 